University of Nebraska - Lincoln

DigitalCommons@University of Nebraska - Lincoln

January 2006

\title{
Effect of Corn Processing in Finishing Diets Containing Wet Distillers Grains on Feedlot Performance and Carcass Characteristics of Finishing Steers
}

\author{
Kyle J. Vander Pol \\ University of Nebraska-Lincoln \\ Galen E. Erickson \\ University of Nebraska-Lincoln, gerickson4@unl.edu \\ Matthew A. Greenquist \\ University of Nebraska-Lincoln, mgreenquist2@unl.edu \\ Terry J. Klopfenstein \\ University of Nebraska-Lincoln, tklopfenstein1@unl.edu \\ Thomas Robb \\ Abengoa Bioenergy, York, Nebraska
}

Follow this and additional works at: https://digitalcommons.unl.edu/animalscinbcr

Part of the Animal Sciences Commons

\footnotetext{
Vander Pol, Kyle J.; Erickson, Galen E.; Greenquist, Matthew A.; Klopfenstein, Terry J.; and Robb, Thomas, "Effect of Corn Processing in Finishing Diets Containing Wet Distillers Grains on Feedlot Performance and Carcass Characteristics of Finishing Steers" (2006). Nebraska Beef Cattle Reports. 119.

https://digitalcommons.unl.edu/animalscinbcr/119
}

This Article is brought to you for free and open access by the Animal Science Department at DigitalCommons@University of Nebraska - Lincoln. It has been accepted for inclusion in Nebraska Beef Cattle Reports by an authorized administrator of DigitalCommons@University of Nebraska - Lincoln. 


\section{Effect of Corn Processing in Finishing Diets Containing Wet Distillers Grains on Feedlot Performance and Carcass Characteristics of Finishing Steers}

\author{
Kyle J. Vander Pol \\ Galen E. Erickson \\ Matt A. Greenquist \\ Terry J. Klopfenstein \\ Thomas Robb ${ }^{1}$
}

\section{Summary}

An experiment evaluated the effects of six corn processing methods in feedlot diets containing 30\% (DM basis) wet distillers grains plus solubles (WDGS). Treatments consisted of whole corn, dry-rolled corn, a dry-rolled/ high-moisture corn mix, high-moisture corn, steam flaked corn, and fine ground corn. The ADG was highest for steers receiving dry-rolled corn, high-moisture corn, or a 50:50 blend of dry-rolled and high-moisture corn. Feed conversion was best for steers receiving high-moisture corn. Interestingly, cattle fed finely ground corn or steam-flaked corn did not gain or convert as well as expected. Results indicate that there is a performance advantage obtained by processing corn as either dry-rolled or high-moisture when included with WDGS in finishing diets.

\section{Introduction}

Recently, the increased availability of wet distillers grains plus solubles (WDGS) has led to a greater number of feedlot producers and nutritionists incorporating this feed into finishing diets. According to past research, incorporating WDGS into feedlot diets results in better performance, with optimum feed conversion observed when included between $30 \%$ and $40 \%$ of the diet (DM basis); (Vander Pol et al., 2006 Nebraska Beef Report). Steam-flaked corn is $12 \%$ and high-moisture corn is $2 \%$ higher in energy than dry-rolled corn (Cooper et al., 2001 Nebraska Beef Report, pp.
54-57). However, in diets containing wet corn gluten feed, high-moisture corn is $8 \%$ higher in energy and steam-flaked corn is $14 \%$ higher in energy than dry-rolled corn based on feed conversion (Macken et al., 2003 Nebraska Beef Report, pp. 25-27).

The objective of this trial was to determine effects of six different corn processing methods as the primary concentrate in diets containing 30\% WDGS (DM basis) on feedlot performance and carcass characteristics of finishing calf-fed steers.

\section{Procedure}

Three-hundred sixty large-framed, crossbred (British x Continental) steer calves $(\mathrm{BW}=701 \pm 34 \mathrm{lb})$ were used in a completely randomized design. Upon arrival to the feedlot, steers were identified, vaccinated, and weaned on smooth bromegrass pastures for approximately three weeks. Five days before the initiation of this trial, steers were limit fed a diet consisting of $50 \%$ wet corn gluten feed and $50 \%$ alfalfa hay (DM basis) at $2 \%$ of BW. Steers were weighed individually on day 0 and day 1 to obtain an accurate initial BW, and all steers were implanted with Synovex-C (Fort Dodge Animal Health, Fort Dodge, IA). Utilizing BW obtained on day 0 , steers were stratified by weight and assigned randomly to pen (10 steers/pen). Pen was assigned randomly to dietary treatment and served as the experimental unit. The overall experimental design used six dietary treatments which were replicated six times, for a total of 36 feedlot pens.

The six dietary treatments (Table 1) consisted of six different corn processing methods or combinations fed at $62 \%$ of diet DM, which were: whole corn (WC), dry-rolled corn (DRC), dry-rolled/high-moisture corn fed at a 1:1 ratio DM basis (DRC:HMC), high-moisture corn (HMC), steam-flaked corn (SFC), and fine-ground (FGC). Basal dietary ingredients consisted of 30\% WDGS, $5 \%$ alfalfa hay fed, and 3\% dry meal supplement (DM basis). Dry matter determinations were conducted weekly on all ingredients by drying samples in a $60^{\circ} \mathrm{C}$ forced air oven for 48-hr. Diets were formulated to meet or exceed the NRC (1996) requirements for metabolizable protein, $\mathrm{Ca}$, and K. Step-up procedure consisted of a 21-day period and four steps fed for $3,4,7$, and 7 days, respectively, where corn replaced alfalfa hay starting at

Table 1. Composition of dietary treatments and formulated nutrient analysis.

\begin{tabular}{|c|c|}
\hline Ingredient $^{\mathrm{a}}$ & $\%$ of diet DM \\
\hline Corn ${ }^{\mathrm{a}, \mathrm{b}}$ & 61.4 \\
\hline WDGS & 30.0 \\
\hline Alfalfa hay ${ }^{b}$ & 5.6 \\
\hline Dry supplement ${ }^{c}$ & 3.0 \\
\hline Limestone & 1.42 \\
\hline Fine ground corn & 0.65 \\
\hline Potassium chloride & 0.47 \\
\hline Salt & 0.30 \\
\hline Tallow & 0.08 \\
\hline Trace mineral premix ${ }^{\mathrm{d}}$ & 0.05 \\
\hline Rumensin- 80 premix ${ }^{\mathrm{e}}$ & 0.018 \\
\hline Vitamin A-D-E premix ${ }^{f}$ & 0.01 \\
\hline Tylan- 40 premix $\mathrm{g}$ & 0.01 \\
\hline \multicolumn{2}{|c|}{ Formulated Nutrient Analysis } \\
\hline Crude protein, \% & 16.1 \\
\hline Calcuim, \% & 0.65 \\
\hline Phosphorus, \% & 0.48 \\
\hline Potassium, \% & 0.65 \\
\hline Sulfur, $\%$ & 0.39 \\
\hline Ether extract, \% & 6.5 \\
\hline
\end{tabular}

${ }^{a}$ Either fine-ground corn, steam-flaked corn, high-moisture corn, dry-rolled/high-moisture corn combination, dry-rolled corn, or whole corn.

${ }^{b}$ Weighted average based on days fed finishing ration and corresponding inclusion.

'Supplement formulated to be fed at 3\% of diet DM.

${ }^{\mathrm{d} P r e m i x}$ contained $10 \% \mathrm{Mg}, 6 \% \mathrm{Zn}, 4.5 \% \mathrm{Fe}$, $2 \% \mathrm{Mn}, 0.5 \% \mathrm{Cu}, 0.3 \% \mathrm{I}, 0.05 \%$ Co.

ePremix contained $80 \mathrm{~g} / \mathrm{lb}^{-1}$ monensin.

fPremix contained $1500 \mathrm{IU}$ vitamin A, $3000 \mathrm{IU}$

vitamin D, 3.7 IU vitamin E per g.

gPremix contained $40 \mathrm{~g} / \mathrm{lb}$ Tylosin. 
Table 2. Performance of steers fed 30\% WDGS and corn from six different processing methods.

\begin{tabular}{lccccccc}
\hline Treatment: $^{\text {a }}$ & FGC & SFC & HMC & DRC:HMC & DRC & WC & SEM \\
\hline Pens, $\mathrm{n}$ & 6 & 6 & 6 & 6 & 6 & 6 & \\
Steers, $\mathrm{n}$ & 60 & 60 & 60 & 60 & 60 & 60 & \\
Days on feed & 168 & 168 & 168 & 168 & 168 & 168 & \\
Performance & & & & & & & \\
Initial BW, lb & 704 & 700 & 700 & 700 & 700 & 700 & 1 \\
Live final BW, lb & $1292^{\mathrm{f}}$ & $1315^{\mathrm{f}}$ & $1353^{\mathrm{gh}}$ & $1351^{\mathrm{gh}}$ & $1377^{\mathrm{g}}$ & $1347^{\mathrm{h}}$ & 9 \\
Adjusted final BW, lb & $1271^{\mathrm{f}}$ & $1303^{\mathrm{g}}$ & $1352^{\mathrm{hi}}$ & $1356^{\mathrm{hi}}$ & $1381^{\mathrm{h}}$ & $1347^{\mathrm{i}}$ & 11 \\
DMI, lb/day & $20.4^{\mathrm{f}}$ & $20.4^{\mathrm{f}}$ & $21.0^{\mathrm{fh}}$ & $21.5^{\mathrm{h}}$ & $22.6^{\mathrm{i}}$ & $23.1^{\mathrm{i}}$ & 0.2 \\
ADG, lb/day & $3.38^{\mathrm{f}}$ & $3.59^{\mathrm{g}}$ & $3.89^{\mathrm{hi}}$ & $3.91^{\mathrm{hi}}$ & $4.05^{\mathrm{h}}$ & $3.85^{\mathrm{i}}$ & 0.06 \\
Feed:gain lb/lb de & $6.15^{\mathrm{fi}}$ & $5.76^{\mathrm{g}}$ & $5.46^{\mathrm{h}}$ & $5.61^{\mathrm{gh}}$ & $5.68^{\mathrm{gh}}$ & $6.07^{\mathrm{i}}$ & 0.09 \\
\hline
\end{tabular}

${ }^{a}$ Where FGC = fine ground corn, $\mathrm{SFC}=$ steam-flaked corn, $\mathrm{HMC}=$ high-moisture corn, DRC:HMC = dry-rolled and high-moisture corn combination, $\mathrm{DRC}=$ dry-rolled corn, $\mathrm{WC}=$ whole corn.

bFinal live BW shrunk $4 \%$.

${ }^{\mathrm{c} C a l c u l a t e d}$ from HCW divided by a common dressing percentage of 63 .

${ }^{\mathrm{d}}$ Calculated from adjusted final body weight.

${ }^{\mathrm{e}}$ Calculated as total feed intake (DM basis) divided by total gain.

f,g,h,i Means in a row with unlike superscripts differ $P<0.05$.

Table 3. Carcass characteristics of steers fed $30 \%$ WDGS and corn from six different processing methods.

\begin{tabular}{|c|c|c|c|c|c|c|c|}
\hline Treatment: ${ }^{\mathrm{a}}$ & FGC & SFC & HMC & DRC:HMC & DRC & WC & SEM \\
\hline $\mathrm{HCW}, \mathrm{lb}$ & $801^{\mathrm{f}}$ & $821^{\mathrm{g}}$ & $852^{\text {hi }}$ & $854^{\mathrm{hi}}$ & $870^{\mathrm{h}}$ & $849^{\mathrm{i}}$ & 7 \\
\hline Dressing \% & 62.0 & 62.4 & 63.0 & 63.2 & 63.2 & 63.0 & 0.3 \\
\hline Liver score ${ }^{b}$ & 0.02 & 0.03 & 0.04 & 0.00 & 0.02 & 0.05 & 0.02 \\
\hline $12^{\text {th }} \mathrm{rib}$ fat, in & $0.45^{\mathrm{f}}$ & $0.51^{\mathrm{fg}}$ & $0.58^{\text {hi }}$ & $0.55^{\mathrm{gh}}$ & $0.62^{\mathrm{i}}$ & $0.59^{\text {hi }}$ & 0.02 \\
\hline KPH fat, \% & $1.87^{\mathrm{f}}$ & $1.92^{\mathrm{fg}}$ & $1.98^{\mathrm{gh}}$ & $1.98^{\mathrm{h}}$ & $2.08^{h}$ & $2.08^{\mathrm{h}}$ & 0.04 \\
\hline Ribeye area, in ${ }^{2}$ & 12.5 & 12.6 & 13.2 & 13.1 & 13.0 & 12.8 & 0.2 \\
\hline Marbling score ${ }^{\mathrm{c}}$ & $487^{\mathrm{f}}$ & $496^{\mathrm{f}}$ & $544^{\mathrm{g}}$ & $528^{g}$ & $540^{g}$ & $534^{\mathrm{g}}$ & 10 \\
\hline \% Choice & 46.1 & 48.3 & 65.0 & 62.4 & 63.5 & 60.0 & 5.3 \\
\hline \% Upper 2/3 Choice & $10.4^{\mathrm{fi}}$ & $6.7^{f}$ & $28.0^{\mathrm{g}}$ & $19.6^{\mathrm{fg}}$ & $29.4^{\mathrm{gh}}$ & $23.3^{\mathrm{ghi}}$ & 5.1 \\
\hline $\mathrm{PYG}^{\mathrm{d}}$ & $3.11^{\mathrm{f}}$ & $3.26^{\mathrm{fg}}$ & $3.45^{\mathrm{hi}}$ & $3.36^{\mathrm{gh}}$ & $3.55^{\mathrm{i}}$ & $3.45^{\mathrm{hi}}$ & 0.05 \\
\hline Yield grade $\mathrm{e}^{\mathrm{e}}$ & $3.06^{\mathrm{f}}$ & $3.22^{\mathrm{f}}$ & $3.37 \mathrm{~g}$ & $3.30^{\mathrm{g}}$ & $3.62^{\mathrm{h}}$ & $3.49^{\mathrm{gh}}$ & 0.08 \\
\hline
\end{tabular}

${ }^{a}$ Where FGC = fine ground corn, $\mathrm{SFC}=$ steam-flaked corn, $\mathrm{HMC}=$ high-moisture corn, $\mathrm{DRC}: \mathrm{HMC}=$ dry-rolled and high-moisture corn combination, $\mathrm{DRC}=$ dry-rolled corn, $\mathrm{WC}=$ whole corn.

bWere $1=\mathrm{A}-, 2=\mathrm{A}, 3=\mathrm{A}+$.

${ }^{\mathrm{c}}$ Where $400=$ Slight $0,500=$ Small 0 .

dPreliminary yield grade measured between $12^{\text {th }}$ and $13^{\text {th }}$ rib.

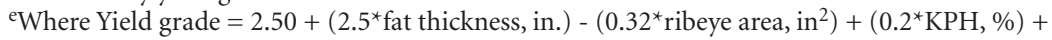
$\left(0.0038^{\star} \mathrm{HCW}, \mathrm{lb}.\right)$

f,g,h,i Means in a row with unlike superscripts differ $P<0.05$.

$45 \%$ of DM for step 1 and decreasing by $10 \%$ for each subsequent step. After 107 days on the finishing diet, alfalfa hay was increased to $7.5 \%$ of diet DM and corn reduced to $59.5 \%$ of diet DM. Steers were fed once daily at 0830 by means of a single axle truck equipped with a Roto-Mix ${ }^{\oplus}$ model 420 (Roto-Mix ${ }^{\circledast}$, Dodge City, Kan.) mixer/delivery box.

Steers were re-implanted on day 66 with Revalor-S ${ }^{\circledast}$ (Intervet, Millsboro, Del.) and fed for a total of 168 days. Before shipping, all pens were weighed separately on a pen scale to determine final live weight and dressing percentage. All final live weight values were shrunk $4 \%$. Steers were slaughtered on day 169 at a commercial packing plant (Greater Omaha Pack, Omaha, Neb.) where hot carcass weights and liver scores were recorded. Following a 48-hour chill, fat thickness/preliminary yield grades, ribeye areas, kidney pelvic heart fat percentages, and USDA called marbling scores were recorded. Yield grade was calculated using the equation $\left(\mathrm{YG}=2.50+\left(2.5^{\star} \mathrm{FT}\right.\right.$, in. $)$ $-\left(0.32^{\star} \mathrm{REA}\right.$, in 2$)+\left(0.2^{\star} \mathrm{KPH}, \%\right)+$ $\left.\left(0.0038^{\star} \mathrm{HCW}, \mathrm{lb}.\right)\right)$ published in the Meat Industry Handbook. Carcass adjusted final body weight, ADG and feed:gain were calculated using hot carcass weight divided by an average dressing percentage of 63 , which was done to minimize error associated with gastrointestinal fill, and to provide an accurate estimate of individual final body weight.

With the exception of the SFC, all corn used was produced from the same seed-corn hybrid (Pioneer 33B51, Pioneer Hybrid International, Johnston, IA) and grown in similar fields under irrigation to reduce the effect of corn hybrid on feeding performance. Dry-rolled corn was processed through a single-roll roller mill. Fine-ground corn was processed through a hammermill to pass through a $0.95-\mathrm{cm}$ screen. Highmoisture corn was harvested in one day at approximately $32 \%$ moisture and ensiled in a plastic silo bag for a minimum of 55-days before air exposure. Steam-flaked corn was produced at a commercial feedlot (Mead Cattle Company, Mead, Neb.), targeted a flake density of $26 \mathrm{lb} /$ bushel, and delivered bi-weekly. Wet distillers grains plus solubles were procured from a commercial ethanol plant (Abengoa Bioenergy, York, Neb.), and delivered on an as needed basis to the research facility (approximately 1X/ week). Based on information obtained from the ethanol plant, the ratio of distillers grains to distillers solubles was 65:35 (DM basis) and contained on average; $32.6 \% \mathrm{DM}, 30.6 \% \mathrm{CP}$, and $12.0 \%$ crude fat.

Data were analyzed using the mixed procedures of SAS (Version 9.1, SAS Inc., Cary, N.C.) as a completely randomized design, with pen serving as the experimental unit.

\section{Results}

Cattle receiving the $\mathrm{DRC}$ or $\mathrm{WC}$ treatments had significantly higher DMI than cattle receiving the FGC, SFC, HMC, and DRC:HMC treatments (Table 2, $P<0.05$ ).

The ADG was highest $(P<0.05)$ for cattle fed DRC, HMC, and 50:50 DRC:HMC treatments. Feed:gain, was lowest for cattle receiving the HMC treatment and highest for cattle receiving the FGC treatment $(P<0.05)$. Cattle receiving the HMC treatment

(Continued on next page) 
had better $(P<0.05)$ feed:gain ratio than cattle fed FGC, SFC, and WC treatments, with a trend $(P=0.09)$ for the HMC treatment to be better than the DRC treatment (5.46 vs 5.68). The HMC treatment was lower in feed conversion because of lower DMI and similar ADG relative to the DRC treatment.

Liver abscess score (Table 3 ) was not different among treatments $(P=$ $0.47)$ which can potentially indicate cattle did not experience a higher incidence of acidosis due to different corn processing methods, or that Tylan $^{\circledR}$ inclusion controlled abscesses. Cattle with the least amount of 12th rib fat were on the FGC treatment, which measured 0.45 in, which indicates that regardless of dietary treatment, cattle achieved a minimum fat thickness indicative of adequate finish. Fat thickness was greatest for cattle receiving the DRC treatment (0.62 in), which was greater $(P<0.05)$ than cattle on the FGC, SFC, WC, and DRC:HMC treatments.
Ribeye area was not different among treatments $(P=0.16)$, however, marbling score was significantly different $(P<0.01)$. Cattle receiving the HMC treatment had the highest marbling score (544) while cattle on the FGC and SFC treatments had the lowest $(P<0.05)$.

There were no significant differences $(P=0.07)$ among treatments for percentage of cattle grading USDA Choice or better. However, only 6.7\% of cattle on the SFC treatment graded upper 2/3 Choice or better, which was lower than every other treatment except the FGC treatment. Cattle receiving the DRC treatment had a significantly higher $(P<0.05)$ calculated yield grade than cattle receiving the FGC, SFC, HMC, and DRC:HMC treatments. The carcass characteristics support the performance data, with cattle fed FGC and SFC being less finished and lower in fat than the other treatments.

In summary, high concentrate finishing diets containing 30\% (DM basis) WDGS are influenced by corn processing method. More specifically, cattle fed 30\% WDGS and DRC yielded higher final body weights, ADG, fat thickness, KPH, and calculated yield grade than cattle fed 30\% WDGS and either FGC, SFC, HMC, DRC:HMC, or WC. However, cattle fed 30\% WDGS and HMC as the concentrate source yielded better feed conversion, and higher marbling scores than cattle fed the same amount of WDGS and either FGC, SFC, DRC:HMC, DRC, or WC. Overall, WDGS is an excellent feed ingredient for finishing diets. It appears that steam-flaking and fine grinding or not processing corn at all (whole corn) are not as favorable as dry-rolling and high-moisture corn processing methods in diets containing 30\% WDGS.

\footnotetext{
${ }^{1}$ Kyle J. Vander Pol, research technician; Galen E. Erickson, assistant professor; Matt A. Greenquist, research technician; Terry J. Klopfenstein, professor, Animal Science, Lincoln; Thomas Robb, Abengoa Bioenergy, York.
} 